\title{
CHANGES IN BEHAVIOR WITH INCREASING EXPERIENCE WITH A NOVEL PREY IN FRY OF THE CENTRAL AMERICAN CICHLID, CICHLASOMA MANAGUENSE (TELEOSTEI: CICHLIDAE)
}

\author{
by
}

\section{AXEL MEYER ${ }^{1}$ )}

(Department of Zoology and Museum of Vertebrate Zoology, University of California, Berkeley, CA 94720, U.S.A.)

\section{Introduction}

Predators become more efficient at dealing with a prey with increasing experience. Although this is a well known phenomenon, the underlying mechanisms are not obvious. The predator may become better at detecting, catching, or handling the prey.

Selection should favor fish that can rapidly increase capture success and that are able to switch prey objects quickly. It may favor variability in responsiveness to novel prey stimuli and this could result in an increased breadth of diet. This may be because prey are probably patchily distributed and the composition of the zooplankton is often variable.

Recruitment of fish stocks is affected by the survival of the young age classes (HJort, 1926; Hunter, 1971). Therefore feeding by fish larvae, especially of commercially important fish species, is of special interest to fisheries scientists (e.g. Ivlev, 1961; Braum, 1963, 1964, 1967; Blaxter, 1962, 1968, 1969; Blaxter \& Staines, 1972; Rosenthal, 1969b; Rosenthal \& Hempel, 1970; Hunter, 1971, 1972; Chitty, 1981).

1) This research was performed in partial fulfillment of the requirements for the M.A. degree at the University of California. The author extends his utmost thanks to George W. BARLOW for advice, encouragement, and constructive criticism. Financial support was provided through Fulbright-Fellowships from the German and the American Governments, and through Teaching and Research Assistantships from the University of California: direct support of the research was provided by grant 18496 to G. W. BARLOw from the National Institute for Child Health and Human Development. I am grateful to H. Greene and S. Glickman who provided helpful criticism on an earlier draft. A. Bingham, R. Francis, W. Rogers, J. Holder, W. Sousa are gladly acknowledged for their suggestions and for bearing with me. For technical assistance, I thank M. Bisset, B. Choi, M. Leong, W. Sousa, and A. Young.

Konstanzer Online-Publikations-System (KOPS)

URL: http://www.ub.uni-konstanz.de/kops/volltexte/2007/3690/

URN: http://nbn-resolving.de/urn:nbn:de:bsz:352-opus-36902 
Fish fry ${ }^{1}$ ) are readily available for observation. With few exceptions (e.g. Ohm, 1958; Ward \& Barlow, 1967; Quertermus \& Ward, 1969; Bergmann, 1971; Noakes \& Barlow, 1973; Wyman \& Ward, 1973; Noakes, 1978; Cole \& Noakes, 1980) studies on the ontogeny of fishes have dealt with feeding behavior (e.g. BRAUM, 1963, 1964, 1967; Rosenthal, 1966, 1969a, b, 1970; Lasker et al., 1970; Houde \& Schekter, 1980, 1981; Hunter, 1972; Twongo \& MacCrimmon, 1976; Ware et al., 1981).

Many authors (e.g. Braum, 1963, 1964; Rosenthal, 1969b; Hunter, 1972) reported on the behavioral sequence of first feeding in fish larvae. It involves the visual fixation of the prey item followed by the assumption of stereoscopic vision. Upon fixation, most larvae assume a S-posture and then lunge forward, attempting to capture the prey (BRAUM, 1963; Rosenthal, 1969a, b; Hunter, 1972).

If the prey notices the fish larvae, it might attempt to escape. Then the fish omits the rest of the behavioral sequence of prey capture (BRAUM, 1963; Rosenthal, 1969a; Hunter, 1972).

Not all fish fry have the same behavioral sequence of prey capture. For example, some species never S-posture before lunging forward at the prey (Rosenthal, 1966: Solea solea).

At the onset of feeding on external food sources, fry do not feed selectively on one type of prey and their capture success varies among the different types of prey. In many species success during first feeding ranges from 1-10\% (Braum, 1963, 1964: Coregonus wartmanni, C. fera; Riley, 1966: Pleuronectes platessa; Blaxter, 1962, 1968; Rosenthal, 1969a, b: Clupea harengus; Rosenthal, 1966: Solea solea; Fonds, 1970: Pomatochistus spec.; Meyer, 1986: Cichlasoma managuense). However it can also reach 30\% (Braum, 1964: Esox lucius), 40-50\% (Chitty, 1981: Anchoa mitchilli, A. lamprotaenia) $70 \%$ (Meyer, 1986: Cichlasoma managuense) or even $100 \%$ (Rosenthal, 1970: Belone belone).

Despite the low capture success of most species at first feeding, the fish rapidly increase their capture efficiency. In herring larvae an increase in capture efficiency to $60-70 \%$ is achieved within 30-35 days (RosentHaL,

$\left.{ }^{1}\right)$ The cichlids used in this experiment were between the protopterygiolarval and the pterygiolarval phase (sensu BALON, 1975, 1979) in their life-history (Fig. 1). I prefer to use the more general and nonspecific term 'fry' for cichlids in this interval of their ontogeny. However, I will use 'larvae' for fish which resemble herring larvae at hatching and at beginning of feeding on external food sources. I make this distinction to emphasize the difference in the developmental stage at the onset of feeding between cichlid fry and those such as herring larvae. 
1969a, b). Снiтtу (1981) observed an improvement in capture success from about $30 \%$ to $70 \%$ in 8 days of feeding experience in two species of anchovy. Hunter (1972) reported an increase in feeding success from about $10 \%$ to about $50 \%$ in 6 days of feeding, and up to about $100 \%$ success in 20 days of feeding.

The type of prey used in experiments and the amount of feeding experience greatly influence the capture success (e.g. Rosenthal, 1969a; Rosenthal \& Hempel, 1970; Meyer, 1985, 1986). Rosenthal (1969a) found that individual herring fry, after a few experiences with a novel prey still do not take the novel prey to the same extent as familiar prey. He suggested that individual fry get trained to respond differentially to a type of prey they can capture with high success. BRYAN (1973) and BRYAN \& LARKIN (1972) described a similar mechanism that resulted in food specialization in individual food-experienced trout.

Theoretical work by Murdoch (1969) and colaborators (Murdoch \& OAten, 1975; Murdoch \& Smyth, 1975; OAten \& Murdoch, 1975) predicted when a predator should switch prey items; they worked out the effects of the predators's behavior on the prey population. Murdoch (1969) defined "switching" as the relative disproportionate predation on one type of prey over another type of prey. "Switching" here simply refers to the change in the type of prey.

In many studies (e.g. Hunter, 1972; Houde \& Sahekter, 1980; ChitTy, 1981) it has been assumed that a change in some morphological character of the predator is correlated with an increase in capture success with increasing experience with a particular prey. For example, total length is closely associated with absolute swimming speed and the faststart ability of a fish (WEBB \& Corolla, 1981). Likewise, weight probably indicates strength. Therefore, length and weight might influence capture success.

Moreover, behavioral as well as in neurological studies of fish reveal that visual acuity increases with the growth of the eye during ontogeny (Müller, 1952; Tamura, 1957; Baerends et al., 1960; Johns, 1981; Hairston et al., 1982; Fernald, 1984). Fish with better visual açuity ought to detect and attack prey at greater distances. Hence, the eye diameter may influence prey capture.

I attempted to distinguish which of the behavioral responses, the ability to detect, catch, or handle the prey and which morphological attributes of the predators changed with increasing experience. The aim of the present study was to describe the behavioral changes of fish fry occurring during increasing experience with a novel prey item. The study will 
depict the relative contribution of morphology and behavior to the observed increase in capture success.

The correlated changes in behavior with increasing experience with novel prey will be discussed for their applicability to concepts like searchimage formation.

\section{Materials and methods}

The young of Cichlasoma managuense are guarded and defended by their parents for about six weeks (McKaye \& Barlow, 1976). During this time, the fry start feeding and develop considerably.

The fish in this experiment were bred in the laboratory and were all siblings from the same spawning event. Fig. 1 shows the developmental stage of the experimental fish. Upon completion of the eleutheroembryonic phase, the time between hatching and the first uptake of nutrients from external food sources (BALON, 1975), the fish were fed with nauplii of Artemia salina for the first 10 days of feeding. The prey type was switched to Daphnia during the subsequent experimental phase. It was not possible to balance the experimental design because fish had a very low capture success with Daphnia at first feeding and could not be sustained on a diet of Daphnia through the first 10 days before the experiment (MEYER, 1985).

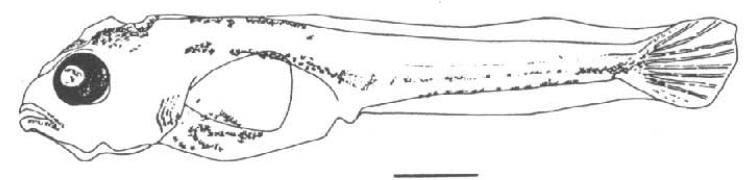

Fig. 1. A fry of Cichlasoma managuense at the developmental stage used in these experiments. The bar represents $1 \mathrm{~mm}$.

Fish of various amounts of prior feeding experience with the novel prey were tested, and changes in behavioral and morphological variables were recorded.

The experimental schedule was as follows (see also Fig. 2): The first group of fish (Trial 1 ), which had no prior feeding experience with the novel prey Daphnia, was transferred from a holding tank into the observation chambers on day 0 for $24 \mathrm{~h}$ acclimation. Trial group 1 was tested on day 1 (I will use the terms group and trial synonymously).

All the other groups of fish also received their first feeding experience with Daphnia on day 1 (in the holding tank). The fish of group 2 were then placed into the observation tanks. Trial 2 fish were acclimated in the chambers from day 1 to day 2 . Observations on group 2 were taken on day 2. This procedure was completed for five groups of fish with up to four previous feeding experiences with Daphnia (Fig. 2). This experimental design was chosen in order to maintain statistical independence and to exclude the confounding effect of fish becoming acquainted with the observation chambers.

Fish with one or more prior experiences with Daphnia (Trial 2-5) were fed in their holding tanks only enough Daphnia for a 5-10 minute feeding period. Each such feeding constituted one feeding experience with the novel prey.

The observation chambers measured $10 \times 10 \times 10 \mathrm{~cm}($ vol. =12). They were arranged in rows of six chambers separated by opaque plastic barriers. Illumination was provided by $20 \mathrm{~W}$ fluorescent light bulbs $20 \mathrm{~cm}$ above and behind the chambers. The temperature 
was $26^{\circ} \mathrm{C} \pm 1^{\circ} \mathrm{C}$. The observation chambers were cleaned after each observation period and refilled with aged water.

Duration of acclimation (up to $24 \mathrm{~h}$ ) appreciably influences the behavior of the fish (pers. obs.). The longer the acclimation the calmer the fish. The fish were not fed during the $24 \mathrm{~h}$ acclimation period (12:12 light dark cycle) in the observation chambers. The observation time was seven min per individual fish and started immediately after prey were introduced into the chamber.

\section{EXPERIMENTAL SCHEDULE:}

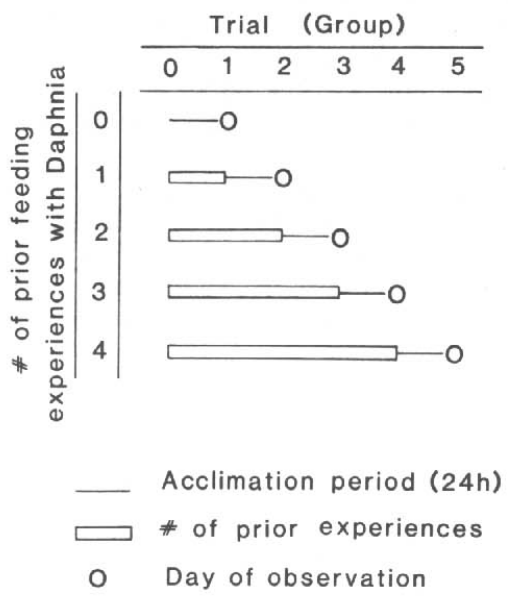

Fig. 2. The experimental schedule. For further explanation see Methods.

The Daphnia were sieved repeatedly to obtain prey of a size comparable (0.2-0.4 mm in diameter) to the pretreatment prey nauplii of Artemia salina. About 150 prey items were introduced into each observation tank. Some nonprey items of the same or smaller size than the prey unavoidably accompanied it. The consumption of the prey during the brief observation period was not sufficient to affect the prey density appreciably.

Only a small number of fish did not feed during the observation period and a few died during acclimation. These fish were excluded from the analysis resulting in unequal sample sizes between the groups. A total of 60 fish were included into the statistical analysis.

Observations during the experiment.

Latency. Latency was the time in sec elapsed between the introduction of the prey and the first attempt of the fish to capture a prey item.

Miss. The fish went through the entire behavioral sequence of prey capture without success. The fish might have aimed in the wrong direction or did not lunge far enough, or the prey evaded the attack, all of which resulted in a missed capture.

Spit-out. Prey capture was sometimes followed by spitting out or losing the prey out of the predator's mouth within a short time after capture. It was not possible to distinguish between a purposeful and an involuntary release of the prey. This behavior was interpreted as indicating some degree of difficulty in handling a prey item.

Prey capture. This was a successful attempt to capture a prey item, followed by swallowing the prey. It was usually not possible to distinguish beween capturing a prey and a 
nonprey item. In the later analysis prey capture was replaced by the actual counts of prey and nonprey items in the stomach.

Measurements and counts.

Immediately after the observations, the fish were taken out of the observation chambers, deeply anaesthetized, and subsequently sacrificed and fixed in $10 \%$ buffered formalin. No prey items were spit-out or lost from the fish's mouth during this process. Later the fish were weighed, measured, and the stomach contents examined. The measurements and counts were done with a stereomicroscope and an ocular micrometer. The balance was accurate to $0.000001 \mathrm{~g}$. The following counts and measures were taken from the preserved fishes:

Total length. This is the length from the tip of the upper jaw to the end of the caudal fin.

Eye diameter. The eye diameter was measured as the orbit length.

Weight. The wet-weight of the fish after the experiment included the ingested prey items.

Capture success. The stomachs were examined and the numbers of prey and nonprey items found were counted. Capture success has sometimes been defined as the ratio of the number of prey items caught to the total number of attempts a fish has made (Rosenthal, 1969a; Houde \& ScheKter, 1981; Hunter, 1972). In this study I defined capture success as the number of prey items caught during the standard observation period, i.e., rate of prey capture. Because I used prey items of comparable sizes this seemed parsimonious. But I will also report the capture efficiency, the percent of successes of the total number of capture attempts, to allow the comparison of capture efficiency in this species with that of other species.

Nonprey. Nonprey were items such as stones, eggshells of Artemia salina, particulate debris, and other items of no nutritional value. They were of similar size as the prey items.

Statistical analysis.

Transformations of the data were conducted when necessary to meet the assumptions of the statistical tests. The transformations included logarithms (for measurements), $\sqrt{ } \mathrm{x}+.5$ (for counts) and arc sin (for percentages). To test for the overall change within a particular behavioral or morphological variable One-Way-ANOVAs were used. Multiple comparisons between the trials within one variable were made with One-Way-ANOVAs (t-tests). The overall probability of making a type I error was maintained at the 0.05 level by adjusting the individual alpha-levels of the pairwise comparisons $(k=5,10$ pairwise comparisons possible, adjusted alpha-value about 0.005) SoKal \& RoHLF, 1981; Dixon \& MASSEY, 1982). Furthermore, multiple stepwise partial regression analysis was used to assess the relative importance of behavioral and morphological variables to the outcome, the increase in capture success with experience with novel prey.

\section{Results}

General comments.

Cichlasoma managuense goes through nearly the same behavioral sequence as other species in which the feeding behavior of fish fry has been observed (references in Introduction). However, the fry did not assume the S-posture with every capture attempt, as has been described in Clupea harengus (RosenthaL, 1969b). In general, the amplitude did not appear 
to be as large as seen in other species in previous studies (BRAUM, 1963; Rosenthal, 1969b; Hunter, 1972). The amplitude of the S-posture, moreover, seemed greater when preying on Daphnia than when preying on their first prey, Artemia. Daphnia is more difficult to catch than Artemia (Meyer, 1985). When the Daphnia noticed the predator, they often escaped and the fry then omited the rest of the behavioral sequence of prey capture.

The capture success increased with increasing experience with the novel prey (One-Way-ANOVA, p<0.005, Fig. 3). Capture efficiency also increased (One-Way-ANOVA, p <0.00001, Fig. 4). The difference in the capture success and capture efficiency between fish with no and

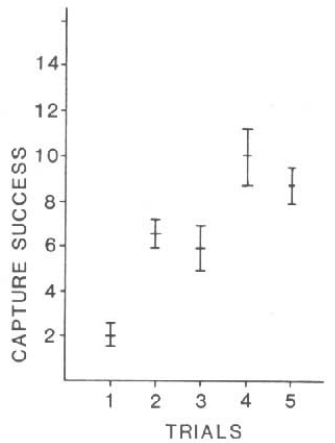

Fig. 3. The capture success (number of prey items in stomach) for each group is represented by a vertical bar giving the mean + /-one S.E. $(n=11,10,11,12,15$ for groups 1 through 5).

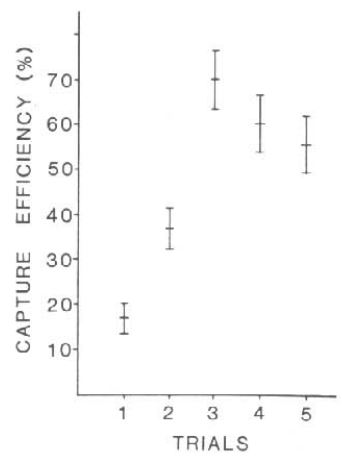

Fig. 4. Capture efficiency (ratio of capture success to attempts) for each group is represented by a vertical bar giving the mean $+/$ - one S.E. $(\mathrm{n}=11,10,11,12$, 15 for groups 1 through 5). 
with one previous feeding experience with the novel prey (trials 1-2) is significant (One-Way-ANOVA, p $<0.0005$, Figs 3 and 4). Thus one prior feeding experience caused a significant increase in the capture success and capture efficiency. The peak capture success was reached after only two prior feeding experiences with a novel type of prey (Fig. 3) (the differences between groups 3,4 and 5 are not significant with the adjusted alpha value). Similarly, only two prior feeding experiences with the novel prey Daphnia were sufficient to reach the highest capture efficiency of $70 \%$ (Fig. 4).

Morphology.

Total length.

Overall the groups differed significantly in size (One-Way-ANOVA, $\mathrm{p}<0.005$, Fig. 5). The difference in size between groups 2 and 4 is significant (One-Way-ANOVA, p<0.001) with the adjusted alpha-value.

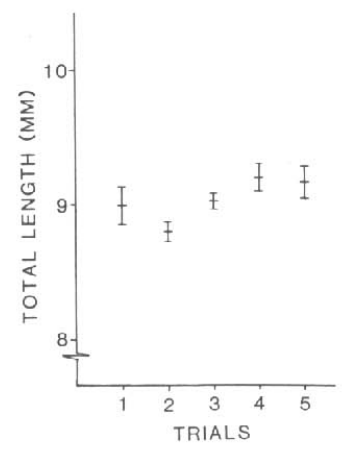

Fig. 5. Total length for each group is represented by a vertical bar giving the mean $+/-$ one S.E. $(n=11,10,11,12,15$ for groups 1 through 5$)$.

\section{Weight.}

The differences between the groups overall were significant (One-WayANOVA, p <0.005, Fig. 6). However, none of the pairwise comparisons showed significant differences (One-Way-ANOVA, p >0.005).

Eye-diameter.

All groups were significantly different from each other (One-WayANOVA, p<0.0001, Fig. 7). Groups 2-4 (One-Way-ANOVA, 
$\mathrm{p}<0.0001$ ), and groups 2-3 (One-Way-ANOVA, $\mathrm{p}<0.001$ ) were significantly different.

Behaviors.

\section{Latency.}

The fish exhibited large variation in latency (Fig. 8). The variation was especially high in fish with no or only one previous experience with the novel prey. The fish in these groups had a latency of around $20 \mathrm{sec}$.

The variation decreased dramatically in groups with more than one previous feeding experience. Their latency was less than 7 seconds. The overall decrease in latency between all groups was almost significant (One-Way-ANOVA, p=0.08, Fig. 8).

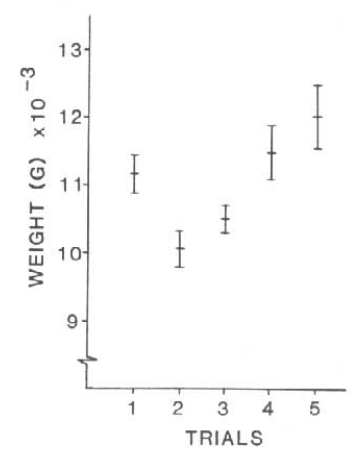

Fig. 6. Weight for each group is represented by a vertical bar giving the mean $+/-$ one S.E. $(\mathrm{n}=11,10,11,12,15$ for groups 1 through 5$)$.

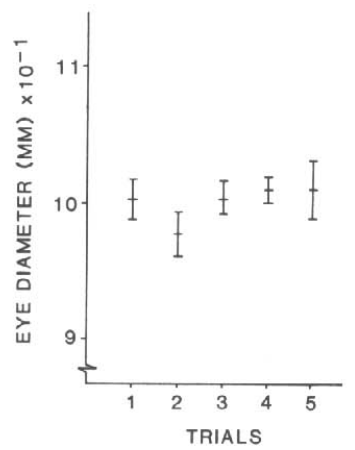

Fig. 7. Eye diameter for each group is represented by a vertical bar giving the mean $+/-$ one S.E. ( $\mathrm{n}=11,10,11,12,15$ for groups 1 through 5$)$. 
Attempts.

The number of attemps, which is the sum of prey captures plus spit-outs plus missess, fluctuated significantly. There, was also considerable variability within the groups. The overall difference was significant (One-Way-ANOVA, p $<0.01$, Fig. 9). The differences were significant between trials 3-5 (One-Way-ANOVA, p<0.005), and 3-4 (One-WayANOVA, p <0.005).

\section{Nonprey.}

At first feeding on extraneous food sources, the fry did not discriminate well. They snapped at prey items but they also attempted to feed on inert

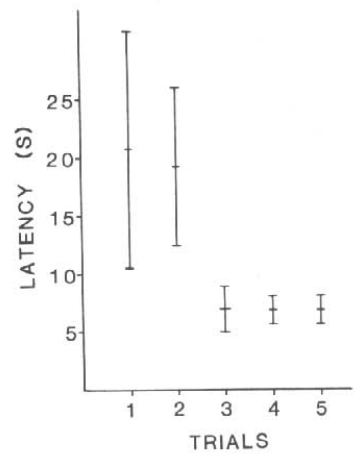

Fig. 8. Latency $(\mathrm{sec})$ to respond after the introduction of prey into the observation chambers, for each group is represented by a vertical bar giving the mean $+/-$ one $\mathrm{S}$. E. $(\mathrm{n}=11,10,11,12,15$ for groups 1 through 5$)$.

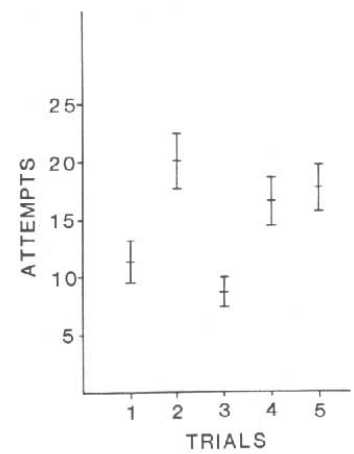

Fig. 9. Attempts to capture prey (sum of prey captures plus spit-outs plus missess), for each group is represented by a vertical bar giving the mean $+/-$ one S.E. $(n=11,10$, $11,12,15$ for groups 1 through 5). 
objects such as detritus, airbubbles, and eggshells of Artemia salina. I also found tiny grains of sand in the stomachs of fish feeding for the first time (MEYer, 1985, 1986). The indiscriminant uptake of nonprey also occurred after switching to the novel prey Daphnia in this experiment. Although nonmoving objects were ingested, the fish snapped preferentially at moving objects over nonmoving ones. Overall the differences between the groups were significant (One-Way-ANOVA, $p<0.05$, Fig. 10).

The variable nonprey exhibited a pattern similar to the variable latency. There was large variation in the number of nonprey items swallowed in the first two groups. However, the mean and the variance decreased from group 3 on (with the exception of group 4). The differences between trials 2-3 (One-Way-ANOVA, p<0.005) and between trials 2-5 (OneWay-ANOVA, $\mathrm{p}<0.001)$ were significant.

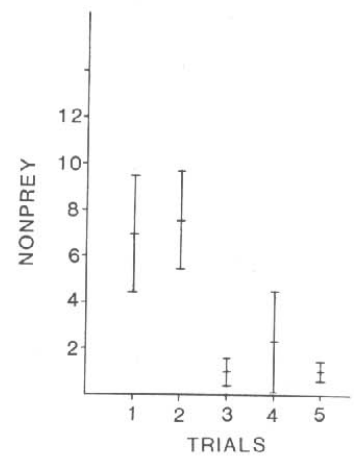

Fig. 10. Number of nonprey found in the stomachs, for each group is represented by a vertical bar giving the mean $+/$ - one S.E. $(\mathrm{n}=11,10,11,12,15$ for groups 1 through 5$)$.

\section{Nonprey/prey.}

The ratio of nonprey to prey items taken (index of selectivity) (Fig. 11) showed a similar pattern as the variables latency time and nonprey (Figs 8 and 10). The change with increasing experience was significant (OneWay-ANOVA, $\mathrm{p}<0.0001$ ). The first group took about 3 nonprey items for each prey item. Group 2 ingested one nonprey item for each prey item. From group 3 on the fish took on average 5 to 6 times more prey than nonprey items. Trials 1-3, 1-4 were significantly different (OneWay-ANOVAs, $\mathrm{p}<0.001$ ). 
Miss.

The number of missed attempts did not change with increasing experience with novel prey. The overall differences were not significant (One-Way-ANOVA, p>0.05, Fig. 12).

\section{Spit-outs.}

Fish sometimes repeatedly spit-out and ingested the prey until it was finally swallowed, lost, or neglected. The number of spit-outs decreased from group 1 to group 3 from about 5.4 to 2.3 spit-outs on average.

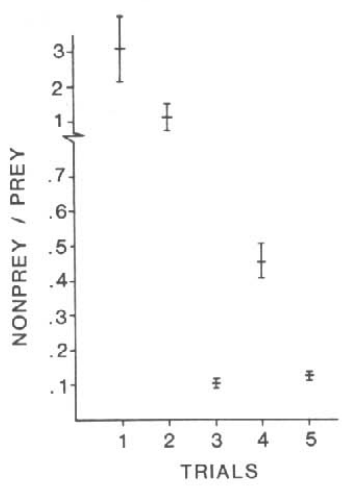

Fig. 11. Ratio of nonprey to prey items taken (index of selectivity), for each group is represented by a vertical bar giving the mean $+/$ - one S.E. $(n=11,10,11,12,15$ for groups 1 through 5).

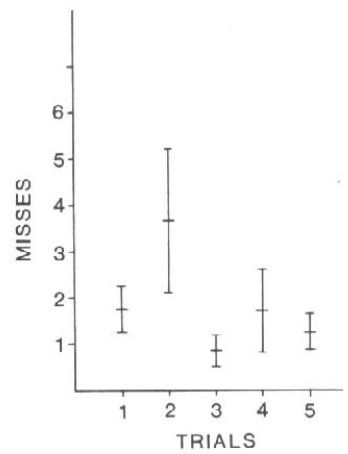

Fig. 12. The number of missed attempts to capture prey, for each group is represented by a vertical bar giving the mean $+/$ - one S.E. $(\mathrm{n}=11,10,11,12,15$ for groups 1 through 5). 
However, it increased in groups 4 and 5 to 4 and 7.3 respectively (Fig. 13). Overall, the differences between the groups were significant (OneWay-ANOVA, $\mathrm{p}<0.05)$. However, none of the pairwise comparisons was significantly different (One-Way-ANOVAs, $\mathrm{p}>0.005$ ).

\section{Handling effort.}

Spit-outs, expressed as a measure of handling effort (spit-outs per prey) may be a better estimate of handling effort (Fig. 14) than the mere number of spit-outs (Fig. 13). The fish decreased their handling effort with increasing experience by using fewer spit-outs per prey item caught (One-Way-ANOVA, p<0.0001). The handling effort decreased from

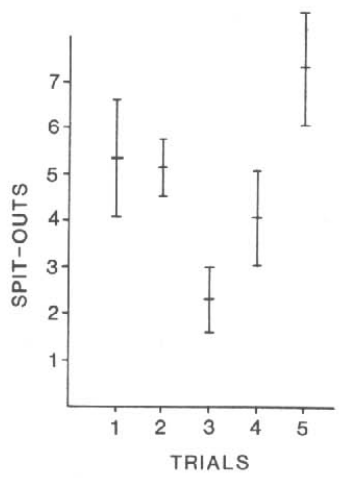

Fig. 13. Spit-outs for each group is represented by a vertical bar giving the mean $+/-$ one S.E. ( $\mathrm{n}=11,10,11,12,15$ for groups 1 through 5$)$.

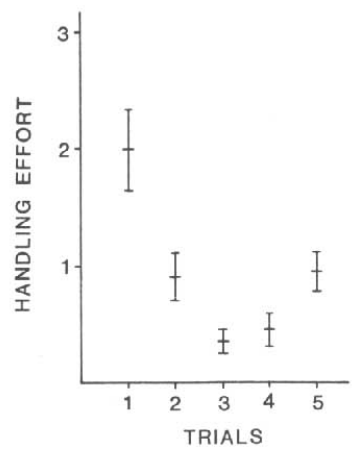

Fig. 14. Spit-outs per prey (handling effort) for each group is represented by a vertical bar giving the mean $+/$ - one S.E. $(\mathrm{n}=11,10,11,12,15$ for groups 1 through 5$)$. 
2.0 spit-outs per Daphnia in group 1 to 0.9 spit-outs in groups 2 to 0.4 spit-outs in groups 3 and 4 . However, the handling effort increased again in group 5 to 0.9 spit-outs per Daphnia caught. The differences between groups 1-3 (One-Way ANOVA, p<0.0005), 1-4 (One-Way-ANOVA, $\mathrm{p}<0.001$ ), and 1-5 (One-Way-ANOVA, $\mathrm{p}<0.005$ ) were significant.

The role of changing morphology and behavior in capture success.

To explain the variation in capture success within all groups I analysed the data with partial multiple stepwise regressions. Capture success was the dependent variable and all morphological and behavioral variables were the predictor variables. The adjusted $\mathrm{R}$-squared value was employed to judge when the greatest part of the variability in the dependent variable had been explained.

The model was calculated as a standardized partial regression equation, so the partial regression coefficients were transformed into b-primes (Sokal \& Rohlf, 1981; Dixon \& Massey, 1983). That is, variables are not expressed in their original units but instead are standardized and expressed as change per standard deviation of the dependent variable. This allows one to compare the relative strength of the contribution of the particular predictor variable in explaining the variation in the dependent variable (Sokal \& Rohlf, 1981; Dixon \& Massey, 1983).

The standardized multiple regression model goes as follows: Capture success $=-8.67+.42$ trials +.40 attempts -.41 weight +.34 eye diameter.

This linear model best fit the data (regression analysis, $F=14.9$, $\mathrm{p}<0.00001$, adjusted R-squared $=.49$ ). The predictor variables "trials" (number of previous feeding experiences +1 ) and "attempts" (total number of capture attempts), weight, and eye diameter best explain the variation in the dependent variable "capture success". Note that trials, attempts and eye diameter were positively correlated with capture success whereas weight was negatively correlated.

A change of 2.5 standard deviations in "trials", "attempts", or "weight" will cause a change of one standard deviation in capture success. The variable "eyediameter"' has to change by three standard deviations to cause the same effect on capture success.

An experienced, persistently trying, light fish with a large eye diameter was found to have a high capture success. 


\section{Discussion}

The fish significantly increased their ability to prey on Daphnia with increasing experience. This increase did not result from an overall increase in the total number of attempts because the mean number of attempts fluctuated significantly but did not increase with increasing experience.

The confinement of my experimental fish in a small chamber for 24 $\mathrm{h}$, coupled with the separation from siblings, might have increased the variability of the fry's motivation. That could partly explain the considerable individual variation in the behaviors observed. RINGLER (1979) noted considerable variability in behaviors in young trout, particularly in the early stages of getting experienced with a novel prey item. Hunter's (1972: 833) figure 9 also exemplifies this pronounced variability. This variability may be caused by a number of factors.

The variability in the weight, as a correlate of the hunger state of the Cichlasoma managuense, may have been large enough to cause the marked differences in the motivation to prey (see Dill, 1983).

Milinski \& LöWENSTEIN (1980) reported for sticklebacks a significant decrease in the time to catch a given number of prey items with increasing experience with their experimental set up. That explanation does not apply to this experiment because none of the fish in this experiment had any prior exposure to the observation chamber.

The increase in the success rate with increasing experience with a new type of prey could be caused by changes in morphology alone or by behavioral changes that have no morphological correlates.

The influence of morphology on capture success.

Rosenthal (1969b) found a positive relationship between the length of the fish and the speed of the behavioral sequence of prey capture by herring larvae. Chiтty's data (1981) suggest that length of fish is an important variable in capture success. Along with increasing size goes an increase in the strength of the fin support and maturation of the jaw apparatus (O'Connel, 1981). Consequently success may be correlated with total length of the fry. However, contrary to previous hypotheses (Rosenthal, 1969a, b; Rosenthal \& Hempel, 1970; Hunter, 1972; Houde \& Schekter, 1980; Chitty, 1981), size of Cichlasoma managuense did not influence the capture success significantly. Similar to my findings, Ringler (1979) and Milinski \& Löwenstein (1980) did not find a significant influence of size on capture success in trout and sticklebacks.

Weight of the fry could influence capture success because it may indicate strength and stamina. A heavier fish, with more muscle, should 
have stronger thrust and hence a greater likelihood of catching prey. On the other hand a lighter fish may be hungrier and therefore motivated to attempt to hunt for the prey more persistently.

I found a correlation between capture success and weight of the fish. Multiple regression analysis did reveal that weight and eye diameter explain a significant portion of the variation in the dependent variable capture success. Weight, however, was negatively correlated with success. That may indicate that the lighter, probably hungrier, fish tended to be more successful. This result may be explained by DiLL's (1983) findings that showed that small changes in the gastric sensation of hunger can strongly influence a fish's behavior.

Visual acuity increases with increase in eye diameter (see references in Introduction). This positive correlation of eye diameter with capture success may suggest an ecological effect of the increase in visual acuity with increasing eye diameter.

Behavioral changes and the formation of search image.

In order to show that a perceptual change in the predator occurred one needs to demonstrate that neither catching ability nor handling proficiency, nor decreasing avoidance of the novel prey brought about the observed changes in capture success (Dawkins, 1971; Krebs, 1973; Curio, 1976).

Misses are a measure of catching ability. The fish's ability to capture prey did not improve significantly with increasing experience (Fig. 12). The regression analysis showed that catching ability did not improve within the first five trials with a novel prey. The predictor variable " "misses" did not explain a significant portion of the variation in capture success. Misses made up only $10-15 \%$ of all capture attempts. It may be, however, that the capture ability improved later with more experience with the prey and therefore contributes to the increase in capture success.

Spit-outs indicated difficulty in handling a particular prey item. The change in the number of spit-outs was significant (Fig. 13). The fry needed to handle (spit-out) the Daphnia less often with increasing experience. They diminished thereby, the risks of loosing the prey through escape behavior of the prey or predation by a competing fish. It may also be that the fish got better in masticating the prey through strengthening of the jaw apparatus and the associated muscles. None of these interpretations can be ruled out by the available evidence.

The decrease in the ratio of spit-outs per prey (Fig. 14) (decrease in handling effort) may reflect an increased handling ability or a change in 
handling tactic. However, it may also mean that the fish learned to distinguish between prey and nonprey once they are captured, i.e., the fish spit-out the nonprey that they did not visually distinguish from a prey item without handling (spiting it out) repeatedly (see also the ratio of nonprey/prey caught, Fig. 11).

The latency of the fish decreased, however the decrease was not quite significant (Fig. 8). This may mean that the fry learned to perceive the novel prey better or avoidance of the novel stimulus decreased.

The fish took fewer nonprey items with increasing experience with Daphnia (Fig. 10). The decrease in the uptake of nonprey items could indicate a perceptual change (TINBERGEN, 1960) or simply demonstrate the buildup of a preference for the new prey.

The prey were not cryptically colored and should not have been hard to perceive. The changes in behavior seem to indicate that the handling efficiency and selectivity increased and the avoidance of the novel prey decreased. Therefore I cannot assume that a perceptual change (sensu Dawkins, 1971; KreBs, 1973) occurred.

Neither WARE's (1972) trout, not BeukemA's (1968) sticklebacks, nor Cichlasoma managuense in this experiment, seem to form a search image in the strict sense of Dawkins (1971) and KREBS (1973).

The influence of age and experience on effective prey switching.

The ability to switch to novel prey and to alter the feeding mode accordingly, might vary with age and species and hence affect community structure. Differing abilities to respond to novel prey might lead to competitive exclusion of the less able predatory species (CROWDER \& Binkowski, 1983).

WARE (1971) found that experience can modify reaction distance. Familiar prey was attacked at twice the distance of unfamiliar prey. Thus prey selection in trout might be influenced by experience. Beukema (1968) observed the same in threespined sticklebacks. Selective predation by fish, with consequences for the composition of prey in the zooplankton, has been shown (e.g. Brooks \& Dowson, 1965; Noble, 1975; ZARET \& Kerfort, 1975).

In many studies predators take the largest prey available. RiNGLER (1979) reported that trout prefer larger prey types over smaller alternative prey. He noted considerable variability, particularly in experiments in which the fish were first exposed to the novel prey. 
Predators, however, tend to trade off prey size against handling effort (e.g. Galbraith, 1967; Gardner, 1981; Gibson, 1983).

In contrast to studies on optimality, handling effort, and prey-size selection, the fish in my study could not choose between type or size of their prey. The two prey were matched in size in order to exclude the effect noted in previous studies (e.g. Blaxter \& Staines, 1972) that the size ratio of prey to fish will strongly influence the capture success.

Cichlasoma managuense appeared to respond readily to new prey stimuli. The latency was short in my experiments. Fish with no prior experience with the novel prey started feeding after about $22 \mathrm{sec}$, and fish with one prior experience started after $20 \mathrm{sec}$. From group 3 on the latency averaged less than $7 \mathrm{sec}$ (Fig. 8). This may suggest that the fry have an open behavioral repertoire, i.e. responded to a greater variety of novel prey stimuli.

RiNGLER (1979) reported much longer latencies of 5-25 min in foodexperienced trout. RingleR's data are similar to Godin's (1978), who also reported latencies of $20 \mathrm{~min}$ in trout after switching to new prey. Both Beukema (1968) and WARE (1971) reported an extended period (of up to 50 trials) during which the novel prey was ignored by the experimental fish. Many of Godin's experimental fish did not switch to the novel prey at all. Predators commonly select the type of prey they have eaten previously when given a choice between a familiar and a novel prey (Rabinowitch, 1968, 1969; Rosenthal, 1969b; Capretta, 1969). Godin's (1978) results, and the reported long latency, may explain a phenomenon often noted in the fish hobbyist literature: it is difficult to get old cichlids to feed on a new type of food.

I attribute the substantial differences between the data of RingleR (1979) and Godin (1978), and those reported here to the large difference in the age of the experimental fish and possible species-specific differences in the ability to switch prey. In older fish, this responsiveness to novel stimuli is reduced or missing (pers. obs.). This hypothesis seems to be supported by BRYAN (1973) who reported that young trout had less "training bias" and responded faster to novel prey. Older trout, however, needed experience with a novel type of prey before they would choose it (WARE, 1971).

Thomas (1977) proposed that in addition to satiation effects, short term positive and negative changes in motivation occur following "eat" and "reject" episodes, respectively. This effect seemed to determine whether or not sticklebacks ate a particular prey item.

Daphnia seemed a much harder prey to catch than Artemia (MEYER, 
1985, and see below). Therefore, inexperienced fry might be deterred from preying on harder to catch and handle prey, Daphnia. After a few trials, however, the fry attained a high capture success when the only available prey was Daphnia.

\section{Differences in features of the prey.}

The capture efficiency at first feeding in Cichlasoma managuense was about $69 \%$ when hunting Artemia as opposed to $16 \%$ when hunting Daphnia (MEYer, 1985, 1986).

The differences in morphology and behavior of the prey might have had a profound influence on the predator's behavior and consequently on its capture success (see Introduction). Other factors could be involved.

Sutterlin \& Sutterlin (1971) showed that chemical stimuli may be important in eliciting strikes by predator.

To the human observer the colors of the prey do not differ strikingly, although the Artemia appear slightly redder than the Daphnia. Visibility and color of prey can influence the behavior of the predator (e.g. Kerfort \& Zaret, 1975; Ohguahi, 1978).

Daphnia occurs in the natural habitat of Cichlasoma managuense but Artemia salina does not. However, the nauplii of Artemia resemble in body shape the larvae of copepods which co-occur in nature with Cichlasoma managuense. Furthermore Artemia is more spindle-like while Daphnia is more oval. Artemia has no natural predators in its hypersaline habitats and thus the larvae probably have not been selected for effective escape behavior.

The movement patterns differ between the types of prey: Artemia nauplii, although "jumping" erratically, move in a more continuous, predictable fashion and "jump" shorter distances than do Daphnia. No escape reponses to the approaching predator was observed in the Artemia. The movement of the Daphnia, on the other hand, was temporally as well as spatially more unpredictable. Daphnia seemed able to make a faster, harder thrust with their antennae than were Artemia. Daphnia also seemed to notice an approaching predator and often escaped successfully.

This difference in movement patterns and morphology between the two types of prey may have caused the significant difference in capture success. Daphnia is more difficult to catch than is Artemia; it also seems to be harder to handle because the fish spit out the prey repeatedly before finally swallowing it (MEYER, 1986). 


\section{Summary}

With increasing experience with the novel prey, Daphnia, the fish became less hesitant to attack Daphnia. The fish took fewer nonprey items per prey item with increased experience. They also became more efficient in handling the novel prey. There was no indication of the formation of a search image.

The multiple regression model revealed that, although the fish grew during the experimental period, their increased size did not contribute significantly to the increase in capture success. Contrary to previous studies size did not influence capture success within the size range used in these experiments.

The individual variation in capture success was large in all groups of Cichlasoma managuense. The most successful predators were the fish who persistantly attempted to catch prey and had the highest number of previous experiences with the novel prey. The morphological variable weight was negatively correlated with capture success, which may suggest that a hungrier fish is more motivated to prey and a more successful predator. An increase in eye diameter brought about an increase in capture success, due probably to an increased visual acuity, hence it may suggest a possible ecological effect of this morphological variable.

\section{References}

Baerends, G. P., Bennema, B. E. \& Vogelzang, A. A. (1960). Über die Änderung der Sehschärfe mit dem Wachstum bei Aequidens portalegrensis (Hensel) (Pisces, Cichlidae). - Zool. Jb. 88, p. 67-78.

Balon, E. K. (1975). Terminology of intervals in fish development. - J. Fish. Res. Bd Can. 32, p. 1663-1670.

- (1979). The juvenilization process in phylogeny and the altricial forms in the ontogeny of fishes. - Env. Biol. Fish. 4, p. 97-101.

Bergmann, H. H. (1971). Untersuchungen zur Verhaltensentwicklung beim Segelflosser Pterophyllum scalare Cuv. Val. - Z. Tierpsychol. 29, p. 343-388.

Beukema, J. J. (1968). Predation by the three-spined stickleback (Gasterosteus aculeatus L.): The influence of hunger and experience. - Behaviour 31, p.1-126.

Blaxter, J. H. S. (1962). Herring rearing IV. Rearing beyond the yolk sac stage. Mar. Res. 1, p. 1-18.

- - (1968). Rearing herring larvae to metamorphosis and beyond. - J. Mar. Biol. Ass. UK 48, p. 17-28.

- (1969). Development: eggs and larvae. - In: Fish physiology (HoAr, W. S. \& RaNDall, D. J., eds) pp. 177-252. Academic Press, New York.

- - \& Staines, M. E. (1972). Food searching potential in marine fish larvae. - In: 4th European Marine Ecology Symposium (D. J. Crisp, ed.) pp. 467-485. Cambridge University Press.

Braum, E. (1963). Die ersten Beutefanghandlungen junger Blaufelchen (Coregonus wartmanni Bloch) und Hechte (Esox lucinus L.). - Z. Tierpsychol. 20, p. 257-266.

- - (1964). Experimentelle Untersuchungen zur ersten Nahrungsaufnahme und Biologie an Jungfischen von Blaufelchen (Coregonus wartmanni Bloch) Weissfelchen (Coregonus fera Jurine) und Hechten (Esox lucinus L.). - Arch. Hydrobiol. Suppl. 528, p. $183-244$.

- - (1967). The survival of fish larvae with reference to their feeding behavior and the food supply. - In: The biological bais of freshwater fish production (S. D. GerKING, ed.) pp. 113-131. Blackwell, Oxford.

Brooks, J. L. \& Dodson, S. I. (1965). Predation, body size, and composition of plankton. - Science 150, p. 28-35. 
BRYAN, J. E. (1973). Feeding history, parental stock, and food selection in rainbow trout. - Behaviour 45, p. 123-153.

- — \& Larkin, P. A. (1972). Food specialization of individual trout. - J. Fish. Res. Bd Can. 29, p. 1615-1624.

Capretta, P. J. (1969). The establishment of food preferences in chicks of Gallus gallus. - Anim. Behav. 17, p. 229-331.

Chiтty, N. (1981). Behavioral observations of feeding larvae of bay anchovy, Anchoa mitchilli and bigeye anchovy, Anchoa lamprotaenia. - Rapp. P.-v. Réun. Cons. int. Explor. Mer. 178, p. 320-321.

Cole, K. S. \& Noakes, D. L. G. (1980). Development of early social behavior of rainbow trout, Salmo gairdneri (Pisces, Salmonidae). - Beh. Proc. 5, p. 97-112.

Crowder, L. B. \& Binkowski, F. P. (1983). Foraging behaviors and the interaction of aliwife, Alosa pseudoharengus and bloater, Coregonus hoyi. - Env. Biol. Fish. 8, p. 105-113.

Curio, E. (1976). The ethology of predation. - Springer, Berlin 250 pp.

Dawkins, M. (1971). Perceptual changes in chicks: another look at the 'search image' concept. - Anim. Behav. 19, p. 566-574.

Dill, L. M. (1983). Adaptive flexibility in the foraging behavior of fishes. - Can. J. Aquat. Sci. 40, p. 398-408.

Dixon, W. J. \& Massey, F. J. Jr (1983). Introduction to statistical analysis. McGraw Hill, 678 pp (4th edition).

Fernald, R. D. (1984). Vision and behavior in an African cichlid fish. - Am. Sci. 72, p. $56-65$.

Fonds, M. (1970). Remark on the rearing of gobies (Pomatoschistus minutus and P. lozanoi) for experimental purposes. - Helgoländer wiss. Meeresunters. 20, p. 620-628.

Galbraith, M. G. Jr (1967). Size-selective predation on Daphnia by rainbow trout and yellow perch. - Trans. Am. Fish Soc. 96, p. 1-10.

GardneR, M. B. (1981). Mechanisms of size selectivity by planktivorous fish: a test of hypothesis. - Ecology 63, p. 571-578.

Gibson, R. M. (1983). Visual abilities and foraging behavior of predatory fish. Trends in Neuroscience 6, p. 197-199.

Godin, J.-G. J. (1978). Behavior of juvenile salon pink salmon (Oncorhynchus gorbuscha Walbaum) toward novel prey: influence of ontogeny and experience. - Env. Biol. Fish. 3, p. 261-266.

Hairston, N. G., Li, K. T. \& Easter, S. S. (1982). Fish vision and the detection of planktonic prey. - Science 218, p. 1240-1242.

HJort, J. (1926). Fluctuations in the year classes of important food fishes. - J. Cons. int. perm. Explor. Mer. 1, p. 5-38.

Houde, E. D. \& Schekter, R. C. (1980). Feeding by marine fish larvae: development and functional responses. - Env. Biol. Fish. 5, p. 315-334.

- - \& - - (1981). Growth rates, rations and cohort consumption of marine fish larvae in relation to prey concentrations. - Rapp. P.-v. Réun. Cons. int. Explor. Mer. 178 , p. $441-453$.

Hunter, J. (1971). Feeding ecology of marine fish larvae. pp. 32-77. - In: Marine fish larvae. Morphology, ecology, and relation to fisheries. pp. 133. University of Washington Press.

- - (1972). Swimming and feeding behavior of larval anchovy Engraulis mordax. - Fish. Bull. 70, p. 821-838.

Ivlev, V. S. (1961). Experimental ecology of feeding of fishes. - Yale University Press, New Haven, 302 pp.

Johns, P. R. (1981). Growth of fish retinas. - Am. Zool. 21, p. 447-458.

Krebs, J. R. (1973). Behavioral aspects of predation. - In: Perspectives in ethology (Bateson, P. P. G. \& Klopfer, P. H., eds) p. 73-111. Plenum Press, New York. 
Lasker, R., Feder, H. M., Theilaker, G. H. \& May, R. C. (1970). Feeding, growth, and survival of Engraulis mordax reared in the laboratory. - Mar. Biol. (Berlin) 5 , p. 345-353.

MaKaye, K. R. \& Barlow, G. W. B. (1970). Competition between color morphs of the Midas Cichlid Cichlasoma citrinellum, in Lake Jiloa, Nicaragua. - In: Investigations of the ichthyofauna of Nicaraguan lakes (Thorson, T. B., ed.) p. 465-475. University of Nebraska Press.

Meyer, A. (1985). Ontogeny of feeding behavior in young Cichlasoma managuense (Teleostei, Cichlidae). - M.A. Thesis. University of California at Berkeley. pp. 109.

- - (1986). First feeding success with two types of prey by the Central American cichlid fish, Cichlasoma managuense (Pisces, Cichlidae): morphology versus behavior. - Env. Biol. Fish. (in press).

Milinski, M. \& Löwenstein, C. (1980). On predator selection against abnormalities of movement, a test of a hypothesis. - Z. Tierpsychol. 53, 325-340.

Müller, H. (1952). Bau und Wachstum der Netzhaut des Guppy (Lebistes reticulatus). Zool. Jb. 63, p. 275-324.

Murdoch, W. W. (1969). Switching in general predators: experiments on predator specificity and stability of prey populations. - Ecol. Monogr. 39, p. 325-354.

- \& OAten, A. (1975). Predation and population stability. - Adv. Ecol. Res. 9, p. 1-131.

- — \& Sмүтн, M. E. B. (1975). Switching in predatory fish. - Ecology 56, p. 1094-1105.

Noakes, D. L. G. (1978). Ontogeny of behavior in fishes: a survey and suggestions. In: The development of behavior (Burghardt, G. M. \& Bekoff, M., eds) p. 103-125. University of Colorado Press.

- - \& Barlow, G. W. B. (1973). Ontogeny of parent-contacting in young Cichlasoma citrinellum (Pisces, Cichlidae). - Behavior 45, p. 222-252.

Noble, R. L. (1975). Growth of young yellow perch (Perca flavescens) in relation to zooplankton populations. - Trans. Am. Fish. Soc. 104, p. 731-741.

Oaten, A. \& Murdoch, W. W. (1975). Predator switching, functional response and stability. - Am. Nat. 109, p. 299-318.

O'Connel, C. P. (1981). Development of organ systems in the northern anchovy, Engraulis mordax, and other teleosts. - Am. Zool. 21, p. 429-446.

OHGuchi, O. (1978). Experiments on the selection against colour oddity of waterflees by three-spined sticklebacks. - Z. Tierpsychol. 47, p. 254-267.

Онм, D. (1958). Die ontogenetische Entwicklung des Kampfverhaltens bei Aquidens portelegrensis Hensel und $A$. latifrons Steindacher (Cichlidae). Verhandl. Deutsch. Zool. Gesel. (Frankfurt Main) 1958, p. 182-194.

Quertermus, C. J. \& Ward, J. A. (1969). Development of two motor patterns used in contacting parents by young orange chromids (Etroplus maculatus). - Anim. Behav. 17 , p. 624-635.

Rabinowitch, V. E. (1968). The role of experience in the development of food preferences in gull chicks. - Anim. Beh. 16, p. 425-428.

- (1969). The role of experience in the development and retention of seed preferences in zebra finches. - Behaviour 33, p. 222-236.

Ringler, N. H. (1979). Selective predation by drift-feeding brown trout (Salmo trutta). - J. Fish Res. Bd Can. 36, p. 392-403.

Riley, J. D. (1966). Marine fish culture in Britain. VII. Plaice (Pleuronectes platessa L.). Post larval feeding on Artemia salina L. nauplii and the effects of varying feeding levels. - J. Cons. int. Explor. Mer. 30, p. 204-221.

Rosenthal, H. (1966). Beobachtungen über das Verhalten der Seezungenbrut. Helgolander wiss. Meeresunters. 13, p. 213-228. 
- (1969a). Verdauungsgeschwindigkeit, Nahrungswahl und Nahrungsbedarf bei Larven des Herrings, Clupea harengus L. - Ber. Dt. Wiss. Komm. Meeresf. 20, p. 60-69.

(1969b). Untersuchungen über das Beutefangverhalten bei Larven des Herings Clupea harengus. - Mar. Biol. (Berlin) 3, p. 208-221.

- - (1970). Anfütterung und Wachstum des Hornhechtes Belone belone. - Helgoländer wiss. Meeresunters. 21, p. 320-322.

- - \& Hempel, G. (1970). Experimental studies in feeding and food requirements of herring larvae (Clupea harrengus L.). - In: Marine food chains (Steele, J. H., ed.) p. 344-364. Oliver and Boyd, Edinburgh.

Sokal, R. R. \& Rohlf, F. J. (1981). Biometry. - 2nd edition Freeman, 859 pp.

Sutterlin, A. M. \& Sutterlin, G. (1970). Taste response in Atlantic salmon (Salmo salar) parr. - J. Fish. Res. Bd Can. 27, p. 1027-1042.

Tномаs, G. (1977). The influence of eating and rejecting prey items upon feeding and food searching behavior in Gasterosteus aculeatus L. - Anim. Behav. 25, p. 52-66.

TAmura, T. (1957). A study of visual percaption in fish, especially on resolving power and accommodation. - Bul. Jap. Soc. Fish. 22, p. 537-557.

Tinbergen, L. (1960). The natural control of insects in pine woods. I. Factors influencing the intensity of predation by song birds. - Archs Néerl. Zool. 13, p. 265-343.

Twongo, T. K. \& MacCrimmon, H. R. (1976). Significance if the timing of initial feeding in hatchery rainbow trout, Salmo gaidneri. J. - Fish. Res. Bd Can. 33, p. 1914-1921.

WARD, J. A. \& BARLOW, G. W. B. (1967). The maturation and regulation of glancing off the parents by young orange chromides (Etroplus maculatus: Pisces-Cichlidae). Behavior 24, p. 1-69.

Ware, D. M. (1971). Predation by rainbow trout (Salmo gairdneri): the effect of experience. - J. Fish. Res. Bd Can. 28, p. 1846-1852.

- (1972). Predation by rainbow trout (Salmo gairdneri): The influence of hunger, prey density, and prey size. - J. Fish. Res. Bd Can. 29, p. 1193-1201.

- - de Mediola, B. R. \& Newhouse, D. S. (1981). Behavior of first-feeding Peruvian anchveta larvae. (Engraulis tingens). - Rapp. P.-v. Reun. Cons. int. Explor. Mer. 178 , p. $467-474$.

Webb, P. W. \& Corolla, R. T. (1981). Burst swimming performance of northern anchovy, Engraulis mordax, larvae. - Fish. Bull. 79, p. 143-150.

WYMAN, R. L. \& WARD, J. A. (1973). The development of behavior in the cichlid fish, Etroplus maculatus (Bloch). - Z. Tierpsychol. 33, p. 461-491.

ZARET, T. M. \& KeRFort, W. C. (1975). Fish predation on Bosmina longirostis: body size versus visibility selection. - Ecology 56, p. 232-237.

\section{Zusammenfassung}

Mit zunehmender Erfahrung mit dem neuen Beuteobjekt Daphnia nahm die Unentschlossenheit, eine Beuteattacke zu initiieren, ab und die Fische nahmen weniger Nichtbeuteobjekte auf. Die Effizienz der Behandlung des neuen Beuteobjekts wuchs mit Erfahrung. Es wird nicht angenommen, dass die Bildung eines Beuteschemas stattfand. Das mehrfache Regressionsmodel brachte zum Vorschein, dass die Länge der Fische den Fangerfolg nicht beeinflusste, obwohl die Fische während des Experiments wuchsen. Im Gegensatz zu früheren Hypothesen wurde hier kein Einfluss der Länge der Fische auf den Fangerfolg festgestellt.

Die individuellen Unterschiede im Fangerfolg waren groß in allen Gruppen von Cichlasoma managuense. Die erfolgreichsten Räuber waren ausdauernd versuchende, beuteerfahrene Fische. Die morphologische Variable "Gewicht" korrelierte negativ mit Fangerfolg, was durch eine von erhöhtem Hunger erzeugte Motivationssteigerung herrühren könnte. Eine Vergrösserung des Augendurchmessers bewirkte eine Erhöhung des Fangerfolges; die Variable Sehschärfe könnte daher ökologisch wichtig sein. 